\title{
Perancangan Media Pembelajaran Produk Kreatif dan Kewirausahaan Berbasis Android di SMK Elektronika Indonesia Bukittinggi
}

\author{
Muhammad Zakir ${ }^{1}$, Hari Antoni Musril ${ }^{2}$ \\ ${ }^{1,2}$ Program Studi Pendidikan Teknik Informatika dan Komputer, Fakultas Terbiyah dan Ilmu Keguruan, IAIN Bukittinggi, \\ Indonesia \\ ${ }^{1}$ ahmadizaki96@gmail.com * \\ * corresponding author
}

\begin{abstract}
This study aims to develop Android-based learning media in the XI class of Creative Products and Entrepreneurship subjects. The type of research used is Research and Development $(R \& D)$ research. Using the 4-D (four $D)$ version of the development model. Consists of $4 D$ define, design, develop, disseminate. The system development model uses the Luther - Sutopo multimedia development model. The results of this study indicate that Android-based learning media developed on the subject. Class XI Creative and Entrepreneurship Products are appropriate for use in learning by teachers and students. Based on several stages of the trial, the learning media is categorized as valid with the feasibility level of the validity test with an average value of 0.90 in a very valid way, the practicality test of the writer gets an average of 1.0 with a very high category, and in the effectiveness test the writer gets an average - The average value of 0.98 in the very effective category, based on the test results of this product, can be useful for teachers, students, and advanced researchers.
\end{abstract}

Article Info

\begin{abstract}
ABSTRAK
Penelitian ini bertujuan untuk mengembangkan media pembelajaran berbasis android pada mata pelajaran Produk Kreatif dan Kewirausahaan kelas XI. Jenis penelitian yang penulis gunakan adalah penelitian Research and Development (R\&D). Menggunakan model pengembangan versi 4-D (four D). 4D terdiri dari define, design, develop, dessiminatte. Model pengembangan sistemnya menggunakan model pengembangan multimedia Luther - Sutopo. Dari hasil penelitian ini menunjukkan bahwa media pembelajaran berbasis android yang dikembangkan pada mata pelajaran Produk Kreatif dan Kewirausahaan kelas XI sudah layak untuk digunakan dalam pembelajaran oleh guru dan siswa. Berdasarkan beberapa tahapan uji coba, media pembelajaran dikategorikan valid dengan tingkat kelayakan uji validitas dengan rata-rata nilai 0,90 yaitu sangat valid, uji praktikalitas penulis mendapatkan rata-rata 1,0 dengan kategori sangat tinggi, dan pada uji efektivitas penulis mendapatkan rata-rata nilai 0,98 dengan kategori sangat efektiv, berdasarkan hasil uji produk ini, dapat bermanfaat bagi guru, siswa dan peneliti lanjutan.
\end{abstract}

\section{PENDAHULUAN}

Pendidikan kejuruan, termasuk Sekolah Menengah Kejuruan (SMK), merupakan
Article history:

Received: Oct. $23^{\text {rd }}, 2020$

Revised: Nov. $23^{\text {rd }}$, 2020

Accepted: Nov. $30^{\text {th }}, 2020$

Keywords: design, learning media, android. 
kejuruan dapat memberikan akses langsung ke pekerjaan atau melanjutkan menuju pendidikan tinggi (Danish: 2014).

Lulusan pendidikan kejuruan harus memiliki serangkaian kompetensi sesuai dengan yang dibutuhkan dunia kerja. Karena itu, semua komponen penyelenggaraan pendidikan kejuruan, seperti kurikulum, tenaga pendidik, fasilitas, manajemen dan proses pembelajaran harus memenuhi standar yang ditentukan. Kualitas pembelajaran sangat mempengaruhi hasil belajar. Pembelajaran yang efektif adalah pembelajaran yang dapat meningkatkan pencapaian kompetensi siswa sedemikian rupa sehingga dapat menunjang keberhasilan siswa di masa mendatang (Coe: 2014). Peran Guru sangat penting dalam pembelajaran. Kualitas Guru sangat mempengaruhi sikap dan perilaku siswa, serta prestasi akademiknya (Blazar: 2016).

Terdapat cukup banyak masalah yang harus dihadapi oleh dunia pendidikan di Indonesia, termasuk Sekolah Menengah Kejuruan (SMK). Masalah-masalah yang dihadapi SMK antara lain rendahnya kualitas sebagian guru, kurangnya partisipasi masyarakat, tingginya tuntutan masyarakat, laju perkembangan teknologi yang sangat pesat, lemahnya proses pembelajaran dan sebagainya.

Pembaharuan pendekatan pembelajaran merupakan salah satu upaya meningkatkan prestasi anak didik. Pembaharuan pendekatan pembelajaran ditujukan untuk meningkatkan prestasi di bidang pendidikan sebagaimana diharapkan agar anak didik lebih siap menghadapi globalisasi. Peningkatan kualitas pembelajaran merupakan tuntutan logis perkembangan ilmu pengetahuan dan teknologi (Iptek) yang semakin pesat.

Sekolah Menengah Kejuruan (SMK) Elektronika Indonesia Bukittinggi adalah sebuah sekolah menengah kejuruan swasta yang berada di Kota Bukittinggi. Sekolah ini adalah salah satu sekolah swasta di Kota Bukittinggi yang bergerak pada pemanfaatan teknologi pada proses pembelajarannya,
Sekolah Menengah Kejuruan (SMK) Elektronika Indonesia Bukittinggi terdapat 2 jurusan, yaitu Teknik komputer dan Jaringan (TKJ) dan Teknik Mesin.

Berdasarkan wawancara peneliti yang dilakukan pada tanggal 10 Februari 2020 di SMK Elektronika Indonesia Bukittinggi dengan guru bidang studi teknik komputer dan jaringan mata pelajaran produk kreatif dan kewirausahaan (PKK) yaitu ibu Febyy Rillyana, S.Pd, beliau menyampaikan bahwa pada saat proses belajar mengajar peserta didik cendrung merasa jenuh dan kurang bersemangat, media pembelajaran yang menggunakan papan tulis dan power point. Beliau juga menyampaikan bahwa pernah ingin merancang sebuah media pembelajaran yang berbasis android akan tetapi saat ini belum juga terwujudkan. Karena keterbatasan pemahaman dan tenaga ahli dalam merancang sebuah media pembelajaran tersebut sampai saat ini masih belum terlaksana dan media yang digunakan saat proses pembelajaran mata pelajaran PKK masih menggunakan media yang umum digunakan seperti Microsoft Powerpoint.

Peneliti juga telah mewawancarai tiga orang siswa SMK Elektronika pada jurusan teknik komputer dan jaringan (TKJ). Peneliti menyimpulkan bahwa media pembelajaran yang digunakan saat ini masih papan tulis dan power point yang menyebabkan siswa cepat bosan, jenuh dan memakan waktu yang cukup lama dalam memahami pelajaran.

Semua siswa jurusan teknik komputer dan jaringan (TKJ) di SMK Elektronika Indonesia Bukittinggi sudah memiliki smarphone android, dengan maraknya penggunaan android dikalangan siswa tersebut mendorong peneliti untuk membuat media pembelajaran teknik komputer dan jaringan (TKJ) SMK Elektronika Indonesia Bukittinggi program studi produk kreatif dan kewirausahaan (PKK) kelas XI semester dua (2) berbasis Android. Pihak sekolah SMK Elektronika Indonesia Bukittinggi memberi izin kepada siswanya untuk menggunakan 
android dalam proses pembelajaran, namun mereka masih kurang maksimal menggunakannya. Kebanyakan mereka hanya memanfaatkannya sebagai alat komunikasi, bermain game dan eksistensi di media sosial. Peneliti berharap dengan adanya media pembelajaran ini para siswa kelas XI dapat meningkatkan motivasi dan merangsang daya kreativitas siswa dan semangat belajar.

Melalui media pembelajaran berbasis android ini siswa akan lebih praktis dan mudah mempelajari tentang materi mata pelajaran Produk Kreatif dan Kewirausahaan (PKK) dan proses pembelajaran menjadi lebih menarik dalam hal ini dibuat dengan mengunakan Adobe Flash CS6. Penggunaan android dalam pengembangan media pembelajaran akan membantu guru dalam menjelaskan meteri pelajaran yang disampaikan kepada siswa.

\section{METODE}

Jenis penelitian yang dipakai dalam penelitian ini adalah Reasearch And Development (penelitian dan pengembangan). Hal ini didukung oleh pendapat Sugiyono yang mendefinisikan metode penelitiaan dan pengembangan sebagai "metode penelitiaan yang digunakan untuk menghasilkan produk tertentu dan menguji keefektivan produk tersebut".

Dalam penelitian ini peneliti menggunakan model pengembangan multimedia versi Luther-Sutopo Menurut Luther, model pengembangan multimedia terdiri dari enam tahap, yaitu concept (pengonsepan), design (pendesainan), material collecting (pengumpulan materi), assembly (pembuatan), testing (pengujian) dan distribution (pendistribusian). Keenam tahap ini tidak harus berurutan dalam prakteknya, tahap-tahap tersebut dapat saling bertukar posisi. Meskipun begitu, tahap concept memang harus menjadi hal yang pertama kali dikerjakan.

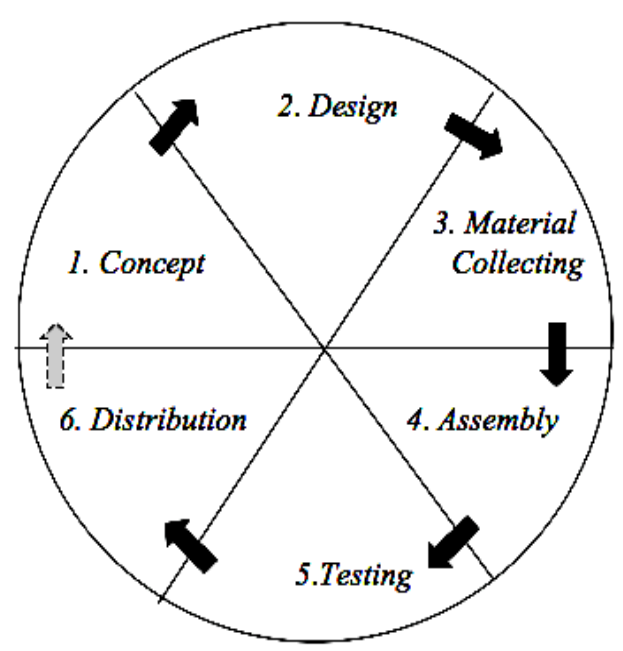

Gambar 1. Tahapan pengembangan multimedia luther-sutopo

\section{HASIL DAN PEMBAHASAN}

Hasil dan Pembahasan merupakan uraian obyektif. Menurut Nurkancana (1986: 62), bahwa prestasi belajar adalah hasil atau taraf kemampuan yang telah dicapai siswa atau peserta didik setelah mengikuti proses belajar mengajar dalam waktu tertentu baik berupa perubahan tingkah laku, keterampilan serta pengetahuan yang kemudian diukur dan dinilai kemudian diwujudkan dalam bentuk angka atau pernyataan.

Model pembelajaran adalah suatu rancangan atau pola yang digunakan sebagai pedoman pembelajaran di kelas. Artinya, model pembelajaran adalah suatu rancangan yang digunakan guru untuk melakukan pengajaran di kelas (Ngalimun: 2014).

Hasil dari penelitian ini adalah sebuah produk berupa aplikasi Media pembelajaran produk kreatif dan kewirausahaan (PKK) berbasis Android untuk kelas XI TKJ SMK Elektronika Indonesia Bukittinggi menggunakan Adobe Flash CS6, Adobe AIR. Media pembelajaran produk kreatif dan kewirausahaan (PKK) ini dibuat sebagai pendukung dari pembelajaran Produk kreatif dan kewirausahaan (PKK) di SMK Elektronika Indonesia Bukittinggi. Diharapkan dengan adanya aplikasi Media pembelajaran produk kreatif dan kewirausahaan (PKK) ini siswa 
lebih bersemangat dalam belajar, dan dapat menambah pemahaman siswa dalam memahami pelajaran dan dapat meningkatkan ketertarikan siswa terhadap materi yang di sampaikan oleh guru, Media pembelajaran produk kreatif dan kewirausahaan (PKK) ini disajikan dalam 8 menu yang terdapat pada menu utama, dimana pada menu utama terdapat Profil, Informasi, Petunjuk, KI\&KD, Materi, Video, Uji Kompetensi Mandiri dan Keluar.

Hasil dari penelitian ini didukung oleh angket yang telah peneliti buat dan sebarkan untuk mendapatkan hasil uji validitas, praktikalitas dan efektivitas terhadap aplikasi Media pembelajaran produk kreatif dan kewirausahaan (PKK) berbasis Android.

Hasil Validitas dari aplikasi Produk Kreatif dan Kewirausahaan (PKK) berbasis android ini dilakukan oleh 3 orang dosen ahli. Hasil lembaran validitas dari 3 orang dosen ahli yaitu Gusnita Darmawati, S.Pd dengan nilai 1,0, Sarwo Derta, S.S., M.Kom dengan nilai 0,98 dan Dr. Supratman Zakir, M.Pd.,
M.Kom dengan nilai 0,71 , mendapatkan nilai akhir 0,90, yang di hitung dengan rumus Statistik Aiken"s V, maka nilai dari aplikasi Produk Kreatif dan Kewirausahaan (PKK) berbasis android ini dinyatakan sangat valid.

Hasil uji kepraktikalitasan produk penelitian ditujukan kepada guru mata pelajaran Produk Kreatif dan Kewirausahaan (PKK). Setelah melakukan proses perhitungan lembar kepraktisan dari guru yaitu Febby Rillyana, S.Pd dengan nilai 1,0, Firdaus Afdal, S.H dengan nilai 1,0 dan Aprianto, S.Pd dengan nilai 1,0 didapatkan nilai akhir 1,0 setelah diterapkan menggunakan moment kappa nilai kepraktikalitasan tersebut berada pada Interval 0,81 - 1,00 dengan kategori sangat tinggi.

Untuk uji efektivitas produk ditujukan kepada lima orang siswa yaitu Arnes Amelia, Bramudya Rakema Syahendra, Donal Eri Adi, Helen Fransiska, Sandi Wanitaril. Setelah melakukan proses perhitungan lembar efektivitas dari lima orang siswa, didapat nilai akhir 0,98 .

Tabel 1. Hasil Nilai Efektifitas

\begin{tabular}{llccc}
\hline No & \multicolumn{1}{c}{ Nama Siswa } & $\begin{array}{c}\text { Sebelum ada } \\
\text { produk }\end{array}$ & $\begin{array}{c}\text { Sesudah ada } \\
\text { produk }\end{array}$ & $\begin{array}{c}\text { Nilai } \\
\text { Efektifitas } \\
\text { Produk }\end{array}$ \\
\hline 1 & Arnes Amelia & 40 & 100 & 1 \\
2 & Bramudya Rakema Syahendra & 36 & 100 & 1 \\
3 & Donal Eri Adi & 36 & 100 & 1 \\
4 & Helen Fransiska & 44 & 96 & 0,92 \\
5 & Sandi Wanitaril & 48 & 100 & 1 \\
& Jumlah & $\mathbf{2 0 4}$ & $\mathbf{4 9 6}$ & $\mathbf{4 , 9 2}$ \\
& Rata-rata & $\mathbf{4 1}$ & $\mathbf{9 9}$ & $\mathbf{0 , 9 8}$ \\
\hline
\end{tabular}

\section{SIMPULAN}

Berdasarkan hasil penelitian dan pembahasan yang telah diuraikan, maka peneliti dapat mengambil kesimpulan yakni Aplikasi media pembelajaran Produk Kreatif dan Kewirausahaan (PKK) berbasis android ini telah dirancang dan dibuat menggunakan Adobe flash Professional CS6 yang menghasilkan output bebentuk apk sehingga bisa dijalankan pada smartphone. Dan aplikasi media pembelajaran Produk Kreatif dan Kewirausahaan (PKK) berbasis android ini dapat membantu para siswa terutama siswa SMK Elektronika Indonesia yang bisa belajar di mana saja tanpa harus membawa buku kemanamana dan hanya memanfaatkan smartphone mereka. Dengan adanya Aplikasi ini diharapkan dapat membantu guru dalam menjelaskan pelajaran terutama pelajaran yang berkaitan dengan gambar video dan contoh lainnya, sehingga dengan adanya aplikasi ini diharapkan 
dapat memudahkan guru dalam mengajar dan memudahkan siswa dalam belajar agar hasil dari proses pembelajaran akan lebih valid, praktis dan efektif.

\section{DAFTAR RUJUKAN}

A. A. N. Utami. 2019. Pengaruh Pembelajaran Produk Kreatif Dan Kewirausahaan Terhadap Minat Berwirausaha Siswa di SMK Pasundan 2 Bandung. J. Chem. Inf. Model., vol. 53, no. 9, pp. 1689-1699, doi: $\quad 10.1017 / \mathrm{CBO} 9781107415324.004$

A. Hafid Firgiawan. 2015. Pengembangan Media Pembelajaran Berbasis Mobile Application Menggunakan Adobe Air For Android Pada Mata Pelajaran Teknik Elektronika Dan Jaringan Untuk Siswa Kelas X Jurusan Rekayasa Perangkat Lunak SMK YPKK 1 Sleman. https://eprints.uny.ac.id/26112/.

Universitas Negeri Yogyakarta Fakultas Teknik.

A. N. Khomarudin and L. Efriyanti. 2018. Pengembangan Media Pembelajaran Mobile Learning Berbasis Android Pada Mata Kuliah Kecerdasan Buatan. $J$. Educ. J. Educ. Stud., vol. 3, no. 1, p. 72, doi: 10.30983/educative.v3i1.543.

B. S. C. Kustandi. 2011. Media Pembelajaran Manual dan Digital. Bogor: Ghalia Indonesia.

H. A. Musril, Jasmienti, and M. Hurrahman. 2020. Implementasi Teknologi Virtual Reality Pada Media Pembelajaran
Perakitan Komputer. JANAPATI J. Nas. Pendidik. Tek. Inform., vol. 9, pp. 83-95.

M. Khanif Syarifudin, 2017. Pengembangan Aplikasi Mobile Learning Menggunakan Adobe Flash CS6 Sebagai Penunjang Pembelajaran Fisika Pada Materi Hukum Newton Untuk Siswa SMA/MA Kelas $X$. http://eprints.walisongo.ac.id/7832/. Universitas Islam Negeri Walisongo Semarang.

Muhson, Ali. 2010. Pengembangan Media Pembelajaran Berbasis Teknologi Informasi. Jurnal Pendidikan Akuntansi Indonesia, Volume 8, Nomor 2, doi: 10.21831/jpai.v8i2.949.

O. Riri, 2019. Pengembangan Media Pembelajaran Digital IPA di SMP N 3 Kecamatan Pangkalan. Journal of Educational Studies, Volume 4, Nomor 2.

Shoimin, A. 2014. Model Pembelajaran Inovatif dalam Kurikulum 2013. Yogyakarta: Ar-Ruzz Media.

Z. Sesmiarni. 2014. Kecerdasan Jamak dalam Pembelajaran IPA di Sekolah Dasar. Jurnal Pendidikan dan Pembelajaran Dasar, Volume 1, Nomor 2, pp. 180189. 